\title{
Effect of Heat Treatment of Wild Cherry Wood on Abrasion Resistance and Withdrawal Capacity of Screws
}

\section{Utjecaj toplinske obrade drva divlje trešnje na otpornost na habanje i čvrstoću držanja vijaka}

\author{
Original scientific paper • Izvorni znanstveni rad \\ Received-prispjelo: 8. 12. 2014. \\ Accepted-prihvaćeno: 6. 11. 2015. \\ UDK: $630 * 812.14 ; 630 * 812.73 ; 630 * 812.791$ \\ doi:10.5552/drind.2015.1440
}

\begin{abstract}
In its wise use, many properties of wood are important. Among these properties, wood abrasion resistance (AR) and withdrawal capacity of screws (WCS) are deemed to be relatively significant. It is well know that heat treatment changes the resistance features of wooden materials by changing the structural characteristics of wood. Within the scope of this study, the effects were investigated of the temperature and duration of heat treatment of Wild Cherry (Cerasus avium (L.) Monench) on its AR and its WCS in the radial direction and tangential direction. The test results indicated that weight loss (WL) and thickness reduction (TR) remained almost the same in the radial direction specimen, but there was significant TR in the tangential direction specimen. As a result of these changes, the abrasion effect of the $S-42$ abrader diminished based on the increase in the number of cycles. However, in both the radial and tangential direction, the WCS decreased to a significantly greater extent in the heat-treated specimens than in the control specimens.
\end{abstract}

Key words: Heat treatment, ThermoWood, abrasion resistance, withdrawal capacity of screws, Wild Cherry wood

SAŽETAK • Za brojne uporabe drva bitna su mnoga njegova svojstva, a među važnijima su otpornost na habanje (AR) i čvrstoća držanja vijaka (WCS). Dobro je poznato da toplinska obrada drva zbog promjene obilježja građe drva mijenja njegova svojstva otpornosti. U sklopu ovog rada istraživani su učinci temperature i trajanja toplinske obrade drva divlje trešnje (Cerasus avium (L.) Monench) na njegovu otpornost na habanje i čvrstoću držanja vijaka u radijalnome i tangencijalnom smjeru. Rezultati istraživanja pokazali su da se gubitak mase (WL) $i$ smanjenje debljine (TR) uzoraka ne pojavljuju u radijalnom smjeru, ali je značajno smanjenje debljine zabilježeno $u$ tangencijalnim uzorcima. Kao rezultat tih promjena, učinak abrazije primjenom $S-42$ abraziva smanjuje se

\footnotetext{
${ }^{1}$ Author is professor at Duzce University, Duzce Vocational School, Program of Furniture and Decoration, Duzce, Turkey. ${ }^{2}$ Author is assistant professor at Duzce University, Faculty of Forestry, Department of Forest Industry Engineering, Duzce, Turkey. ${ }^{3}$ Authors are professors at Istanbul University, Faculty of Forestry, Department of Forest Industry Engineering, Istanbul, Turkey. ${ }^{4}$ Author is professor at Bartın University, Faculty of Forestry, Department of Forest Industry Engineering, Bartın, Turkey.

${ }^{1}$ Autor je profesor Sveučilišta u Duzceu, Strukovna škola Duzce, Program namještaja i uređenja, Duzce, Turska. ${ }^{2}$ Autor je docent Sveučilišta u Duzceu, Šumarski fakultet, Odjel za industrijsku preradu drva, Duzce, Turska. ${ }^{3}$ Autori su profesori Sveučilišta u Istanbulu, Šumarski fakultet, Odjel za industrijsku preradu drva, Istanbul, Turska. ${ }^{4}$ Autor je profesor Sveučilišta u Bartınu, Šumarski fakultet, Odjel za industrijsku preradu drva, Bartın, Turska.
} 
s povećanjem broja ciklusa. Međutim, i u radijalnome i u tangencijalnom smjeru znatno se smanjuje čvrstoća držanja vijaka toplinski obrađenih uzoraka u usporedbi s kontrolnim uzorcima.

Ključne riječi: toplinska obrada, ThermoWood, otpornost na habanje, čvrstoća držanja vijaka, drvo divlje trešnje

\section{INTRODUCTION}

\section{UVOD}

Wooden material has certain undesirable features, such as the change of dimensional stability, biological degradation, and color change, but wooden materials are still used extensively in many products. These adverse features reduce the lifetime and value of wooden material. Currently, it is possible to extend the lifetime and increase the value of wooden materials by various methods that upgrade the features of the materials. Heat treatment of wood is one such method (Kocaefe et al., 2008; Gunduz et al., 2008).

ThermoWood is one of the heat treatment methods developed in the 1990s by VTT Technical Research Centre of Finland. In this method, wooden material is heated at a minimum of $190{ }^{\circ} \mathrm{C}$ in steam. The ThermoWood treatment method enhances the properties of wooden material, e.g., the color of the wooden material darkens and becomes more stable against the exchange of moisture. Moreover, the wooden material gains the value of thermal isolation. If a sufficiently high temperature is used in the treatment, the wooden material becomes more resistant to decomposition. However, the bending resistance of the wooden material decreases (Anonymous, 2003).

From this perspective, the identification of the resistance for various kinds of woods treated by the ThermoWood method can be significant in determining appropriate areas for using the wood. For instance, ThermoWood treated wood can be used as a facade lining for such areas as saunas, bathrooms, and garden furniture (Anonymous, 2003). For use in such areas, AR and WCS, as well as the physical and mechanical properties of the wood, are taken into consideration.

The AR, both heat-treated and untreated, wood is important for such areas as wooden floors, decks, and staves. Abrasive forces on wooden materials result in various effects. There are various methods and devices to measure the resistance of wooden materials to abrasion. However, this issue has been studied extensively because of certain difficulties in the measurement of the resistance of wooden material to abrasion (Berkel, 1970).

Therefore, it is necessary to identify the resistance of wooden material to abrasion and classify it for related areas of use. Despite these difficulties, it has been possible to predict the abrasion levels of various types of wooden materials based on other properties of the materials, such as weight loss, volume reduction, surface roughness, and energy consumption for a defined level of abrasion (Brischke et al., 2004).

Abrasion resistance is determined for various materials according to weight loss during an abrasion test. For example, the Taber Abrasor Method (TAM) was developed to determine the abrasion resistance of high Pressure-Laminated (HPL) panels (DIN EN 438-2, 2005). The abrasion resistance of any solid wooden material can be measured by this method. Obviously, the principle of this testing method is not suitable for testing solid wood and thermally treated materials, even if it is possible to get board-like specimens of at least $120 \mathrm{x}$ $120 \mathrm{~mm}^{2}$. Additionally, the wastage of sandpaper is very high due to plugging (Brischke et al., 2004).

Swaczyna et al. (2011) measured abrasion resistance compared to TR and WL with TAM, according to PN-EN ISO 5470-1:2001 standards and published the results. In the study, they found that TR was $0.17 \mathrm{~mm}$ and WL was $0.25 \mathrm{~g}$ in untreated Cherry Wood.

Taking into consideration the connecting techniques applied on products made of wooden material, it seems that similar methods are used in heat-treated and untreated wooden material. From this perspective, connecting with screws would be better in heat-treated materials. A sinker and a tap hole must be prepared on hardwood, medium-density fiberboard, and other fragile materials. Stainless steel screws and embedding screw heads are preferred for outdoor usage and other humid conditions. Stove bolts give best connecting-resistance results. Self-locking screws can be used without a tap hole on ThermoWood (Anonymous, 2003).

Kariz et al. (2013) measured the withdrawal of screws in radial direction and tangential direction on heat-treated spruce wood at 150, 170, 190, 210, and $230{ }^{\circ} \mathrm{C}$. The results indicated that there was a greater reduction in WCS for thermal modification conditions, and they concluded that deformation increased at higher temperatures based on the analysis of the images of the deformed surface left by the screws. In their study, in which they suggested the use of larger diameter screws and deeper penetration for connecting heat-treated materials, they also recommended that the distance between screws be increased to attain sufficient resistance compared with wooden material that was not heat-treated.

Wild Cherry, a valuable wood in the forest products industry, is used extensively in cabinet making and wood turning. Recently, the use of wild cherry wood has grown in popularity in Turkey and surrounding countries due to high demand for this species. A relatively small amount of research information is available concerning Wild Cherry tree ecology, biology, and genetics of Turkish forestry resources and increased efforts are being encouraged by economic incentives and other benefits (Eşen et al., 2005).

Heat treated wooden materials, unlike products made available by conventional methods, can be evaluated without any protective surface treatment in places where the changes of temperature and relative humidity are intense or in the areas where contact with water is expected. Therefore, the determination of AR is of great importance. It is also important to consider 
the issue of the performance and quantity of fasteners for heat treated wood in furniture production for similar places. A large number of tree species relative to both issues has not been adequately researched. Thus, in this study, efforts were made to determine the values of AR and WCS in heat treated Wild Cherry Wood. The results should fill both of the mentioned information gaps and form a basis for future studies in this important area. In this way, when determining the values of AR and WCS, the applicability of the chosen method was also evaluated.

Tests for AR and WCS were performed in radial and tangential directions. For the determination of AR, both WL and TR were measured in the test samples. This study was also focused on the applicability of the Taber method. The machine was stopped in the loop of 0-250 to determine the effect of the S-42 abrader, and, after cleaning the piece with a brush, its weight was measured, and the test was continued. Depending on the results found in the loops of 0-250 and 250-500 in TR and WL for AR, the effects of aging of the abrasive material were also assessed.

\section{MATERIALS AND METHODS 2. MATERIJALI I METODE}

\subsection{Materials}

\subsection{Materijali}

Five Wild Cherry trees with a breast height diameter of 30 to $50 \mathrm{~cm}$ were obtained from Duzce Forest Enterprises. Trees were chosen according to TS 4176, 1984 and cut to specimens according to TS 2470, 1976. Later, the wood was heat treated in accordance with the ThemoWood method in the Novawood Factory in Gerede/Bolu at 190 and $212{ }^{\circ} \mathrm{C}$ for 1 and $2 \mathrm{hr}$. Five variations along with an untreated group were formed, i.e., untreated (UT); $190{ }^{\circ} \mathrm{C}$ and $1 \mathrm{hr}\left(\mathrm{HT}_{1}\right) ; 190{ }^{\circ} \mathrm{C}$ and $2 \mathrm{hr}\left(\mathrm{HT}_{2}\right) ; 212^{\circ} \mathrm{C}$ and $1 \mathrm{hr}\left(\mathrm{HT}_{3}\right)$; and $212^{\circ} \mathrm{C}$ and $2 \mathrm{hr}$ $\left(\mathrm{HT}_{4}\right)$. In order to determine $\mathrm{AR}$, specimens with the dimensions of $100 \times 100 \times 10 \mathrm{~mm}$ were prepared according to TS EN 15185, 2013 and to determine WCS, specimens with the dimensions of $50 \times 50 \times 20$ mm were prepared according to TS EN 320, 1999.

\subsection{Method}

\subsection{Metode}

The number of test samples was determined according to TS EN 15679, 2010. Following the heat treatment of 100 specimens, 20 for the radial and tangential tests repeated five times, were prepared to be used in the AR and WCS tests. Later, the specimens prepared for AR and WCS were kept at the temperature of $20 \pm 2{ }^{\circ} \mathrm{C}$ and the relative humidity of $60 \pm 5 \%$ until their weights became stable.

\subsubsection{Determination of abrasion resistance \\ 2.2.1. Određivanje otpornosti na habanje}

The AR values of the control and heat treated specimens were determined by using a Taber ${ }^{\circledR}$ Rotary Abraser 5135. The test specimens were mounted on a platform turning on a vertical axis against the sliding rotation of two abrading wheels, with one wheel rubbing the specimen toward the periphery, and the other wheel rubbing inward toward the center. The test specimens were abraded using loads of $1000 \mathrm{~g}$. After every 250 cycles, the devices were stopped and the specimens were weighed, after which the devices resumed, and, at 500 cycles, both the weights and thicknesses of the specimens were determined. The test results were used to calculate the percentages changes in WL and TR by equations (1) and (2). S-42 sandpaper was used as the abrasive, and it was changed after every 500 test cycles.

$$
W L=\frac{\left(W_{\mathrm{E}}-W_{1}\right)}{W_{1}} \cdot 100
$$

$W L=$ Weight loss $(\%), W_{1}=$ Initial weight $(\mathrm{g}), W_{\mathrm{E}}=$ Final weight $(\mathrm{g})$

$$
T D=\frac{\left(T_{\mathrm{E}}-T_{1}\right)}{T_{1}} \cdot 100,
$$

where $T D=$ decrease in thickness $(\%), T_{1}=$ initial thickness $(\mathrm{mm})$, and $T_{\mathrm{E}}=$ final thickness $(\mathrm{mm})$.

Figs. $1 \mathrm{a}$ and $\mathrm{b}$ show images of radial and tangential specimens after 500 cycles. (a)
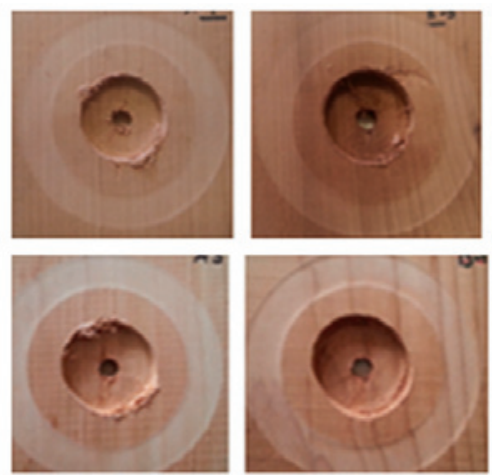
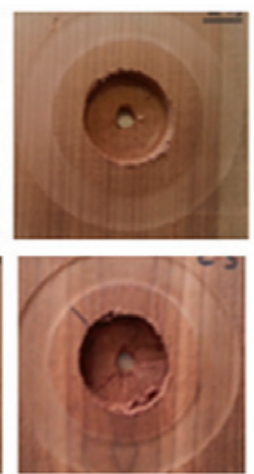
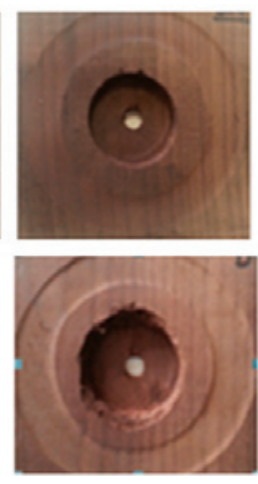
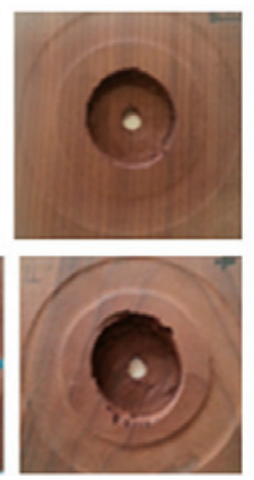

Figure 1 Images of specimens after the experiment: (a) radial specimens; (b) tangential specimens Slika 1. Fotografije uzoraka nakon eksperimenta: a) radijalni uzorci, b) tangencijalni uzorci 

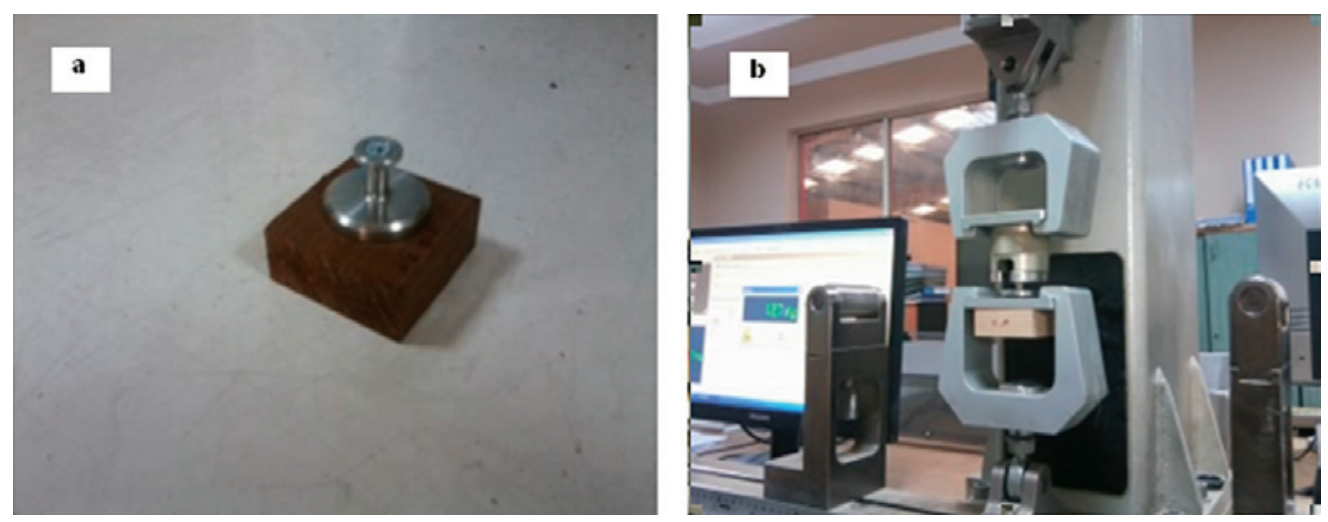

Figure 2 (a) Preparation of the specimen; (b) conducting the experiment on the IMAL IB600 test device Slika 2. a) Priprema uzorka, b) provođenje ispitivanja na uređaju IMAL IB600

\subsubsection{Determination of withdrawal capacity of screws} 2.2.2. Određivanje čvrstoće držanja vijaka

Specimens used to assess the withdrawal capacity of screws were prepared according to TS EN 320, 1999. In order to determine WCS, specimens with the dimensions of $50 \times 50 \times 20 \mathrm{~mm}$ were prepared according to TS EN 320. The tests were conducted using the Laboratory Testing Machine, IMAL IB600. The IB600 has been designed to conduct a series of laboratory tests on wood-based samples, particleboard samples, MDF, OSB or similar. Simple operations enable the operator to programme and perform the tests required for board quality control (Anonymous, 2014). The machine consists of (Anonymous, 2014):

- A motorised column capable of highly accurate speed control, fitted with a two-way (push and pull) load cell, on which it is possible to mount special utensils to perform the individual tests,

- A precision weighing scale,

- A dimensions gauge,

- PC, monitor and printer,

- Utensils for conducting the tests.

Figs. $2 \mathrm{a}$ and $\mathrm{b}$ show the screw placed in the WCS test specimen and the test being conducted, respectively.

In this experiment, the nominal size of the screw was $4.2 \times 38 \mathrm{~mm}$, according to TS 432-1 EN ISO 1478, and steel screws with a pitch of $1.4 \mathrm{~mm}$ were used without drilling the wood (Fig. 3).

For the abrasion resistance and withdrawal capacity of screws, all multiple comparisons were first subjected to an analysis of variance (ANOVA), and significant differences between mean values of control and treated samples were determined using Duncan's multiple range test. The experimental values obtained were evaluated with SPSS 15.0 for Windows Evaluation Version.

\section{RESULTS AND DISCUSSION} 3. REZULTATI I RASPRAVA

\subsection{Abrasion resistance}

\subsection{Otpornost na habanje}

Standard deviation (SD), Duncan test results (D), and arithmetic mean (M) for WL and TR caused by the abrasion in the radial and tangential test samples are given in Table 1.

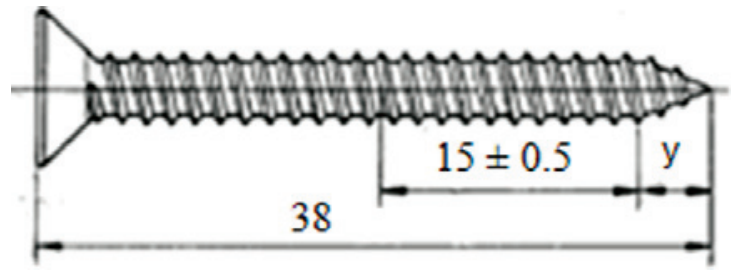

Figure 3 Dimensions of screws used in the experiment Slika 3. Dimenzije vijka rabljenog u eksperimentu

As shown in Table 1, it was found that TR and WL did not change; however, UT for both the 0-250 and the 250-500 loops in the radial test samples changed and WL was also greater in the 0-250 loop than in the 250-500 loop in all variations. The maximum WL occurred in UT, whereas the minimum WL occurred in the variation of HT4; WL in the HT4 samples was about $30 \%$ less than in the UT samples. The maximum $\mathrm{WL}$ in all experimental designs of radial test samples occurred in the UT samples. The percentage changes in WL that occurred in HT compared to those in UT in the total amount of loops of the radial test samples are given in Figs. $4 \mathrm{a}$ and $\mathrm{b}$.

Unlike the radial samples, statistically significant differences in WL were determined in all groups except for HT1 in the 0-250 loop and in all heat treated test samples in the 0-250 loop in the tangential test samples. WL occurred in the 0-250 loop samples to a greater extent than that of the 250-500 loop in all variations of tangential surfaces. In the tangential test samples, the maximum WL of tangential direction occurred in HT4, while the minimum WL occurred in UT. The WL changes in the total loop amount that occurred on tangential surfaces are given in Fig. 4b.

Welzbacher et al. (2009) reported that there were no difference in resistance to abrasion between beech and thermally modified beech timber, whereas a significantly higher mass loss by abrasion of thermally modified beech timber compared to controls was determined by the Shaker test. However, in both cases the abrasion in terms of mass loss of thermally modified beech timber was significantly lower compared to larch heartwood, which represents a commonly used decking material.

The TR values are also shown in Table 1 along with the WL results. Accordingly, it was determined 
Table 1 Weight loss (WL) and thickness reduction (TR) as percent

Tablica 1. Gubitak mase (WL) i smanjenje debljine (TR) izraženo u postocima

\begin{tabular}{|c|c|c|c|c|c|c|c|}
\hline \multirow{3}{*}{$\begin{array}{l}\text { Test } \\
\text { samples } \\
\downarrow U z o r c i\end{array}$} & & \multicolumn{4}{|c|}{ WL } & \multicolumn{2}{|c|}{ TR } \\
\hline & & \multicolumn{2}{|c|}{$\begin{array}{c}\text { Radial } \\
\text { radijalno }\end{array}$} & \multicolumn{2}{|c|}{$\begin{array}{c}\text { Tangential } \\
\text { tangencijalno }\end{array}$} & $\begin{array}{c}\text { Radial } \\
\text { radijalno }\end{array}$ & $\begin{array}{c}\text { Tangential } \\
\text { tangencijalno }\end{array}$ \\
\hline & Cycle $\rightarrow$ & $0-250$ & $250-500$ & $0-250$ & $250-500$ & \multicolumn{2}{|c|}{$0-500$} \\
\hline \multirow{2}{*}{ UT } & $\mathrm{M}$ & $0.80 \mathrm{~A}^{*}$ & $0.36 \mathrm{~A}$ & $0.50 \mathrm{~A}$ & $0.23 \mathrm{~A}$ & $2.02 \mathrm{~A}$ & $1.53 \mathrm{~A}$ \\
\hline & SD & 0.24 & 0.3 & 0.05 & 0.03 & 0.37 & 0.39 \\
\hline \multirow{2}{*}{$\mathrm{HT}_{1}$} & $\mathrm{M}$ & $0.55 \mathrm{AB}$ & $0.30 \mathrm{~A}$ & $0.46 \mathrm{~A}$ & $0.34 \mathrm{~B}$ & $1.69 \mathrm{~A}$ & $2.13 \mathrm{AB}$ \\
\hline & SD & 0.07 & 0.05 & 0.07 & 0.8 & 0.55 & 0.39 \\
\hline \multirow{2}{*}{$\mathrm{HT}_{2}$} & $\mathrm{M}$ & $0.67 \mathrm{~A}$ & $0.39 \mathrm{~A}$ & $0.76 \mathrm{~B}$ & $0.56 \mathrm{C}$ & $1.80 \mathrm{~A}$ & $2.44 \mathrm{AB}$ \\
\hline & SD & 0.02 & 0.02 & 0.03 & 0.06 & 0.07 & 1.18 \\
\hline \multirow{2}{*}{$\mathrm{HT}_{3}$} & $\mathrm{M}$ & $0.59 \mathrm{~A}$ & $0.37 \mathrm{~A}$ & $0.75 \mathrm{~B}$ & $0.63 \mathrm{BC}$ & $1.82 \mathrm{~A}$ & $3.25 \mathrm{~B}$ \\
\hline & SD & 0.11 & 0.03 & 0.09 & 0.09 & 0.01 & 1.03 \\
\hline \multirow{2}{*}{$\mathrm{HT}_{4}$} & $\mathrm{M}$ & $0.50 \mathrm{~A}$ & $0.31 \mathrm{~A}$ & $0.85 \mathrm{~B}$ & $0.73 \mathrm{D}$ & $1.82 \mathrm{~A}$ & $2.99 \mathrm{~B}$ \\
\hline & SD & 0.08 & 0.07 & 0.17 & 0.10 & 0.00 & 1.24 \\
\hline
\end{tabular}

$(*)$ The letters express the homogeneity groups according to Duncan test results. / Slova označuju homogene grupe prema Duncanovu testu.

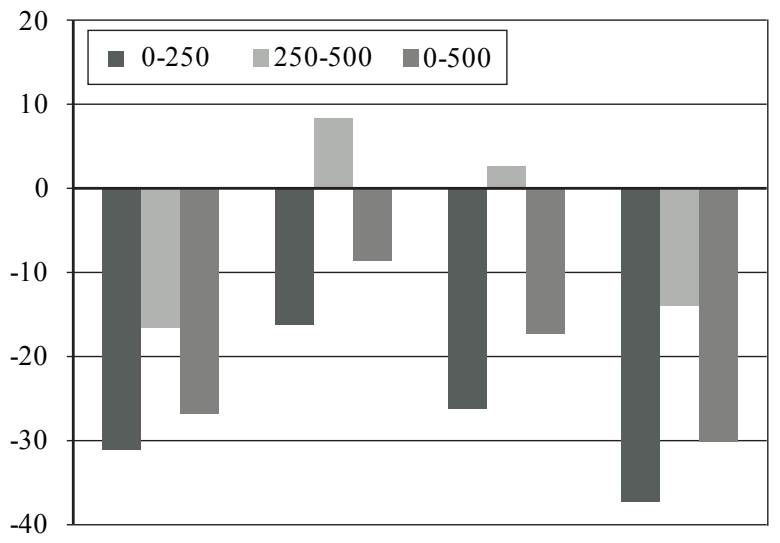

a

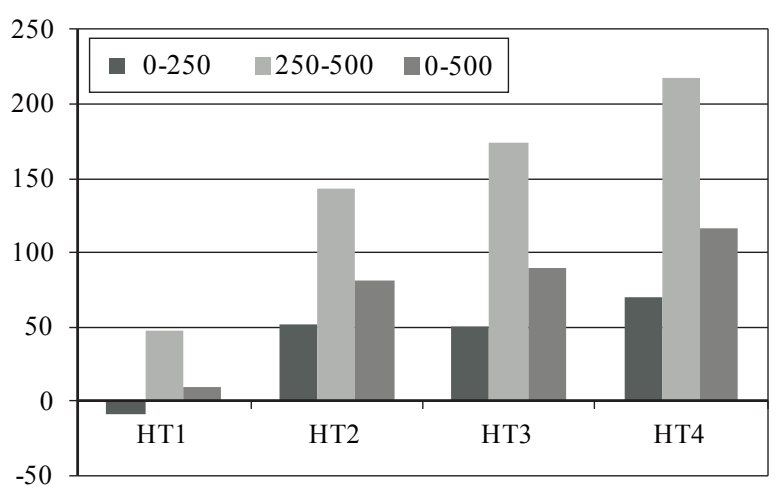

b

Figure 4 (a) Percentage change of WL in the radial samples; (b) Percentage change in the tangential test samples according to UT

Slika 4. a) Postotna promjena WL-a radijalnih uzoraka, b) postotna promjena WL-a tangencijalnih uzoraka u odnosu prema kontrolnom uzorku

that, although there is no statistically significant difference between UT and all heat treated test samples in terms of TR in radial test samples, there were differences between HT variations and UT in the tangential test samples. The variations in thickness that occurred in the total loop are shown in Fig. 5.

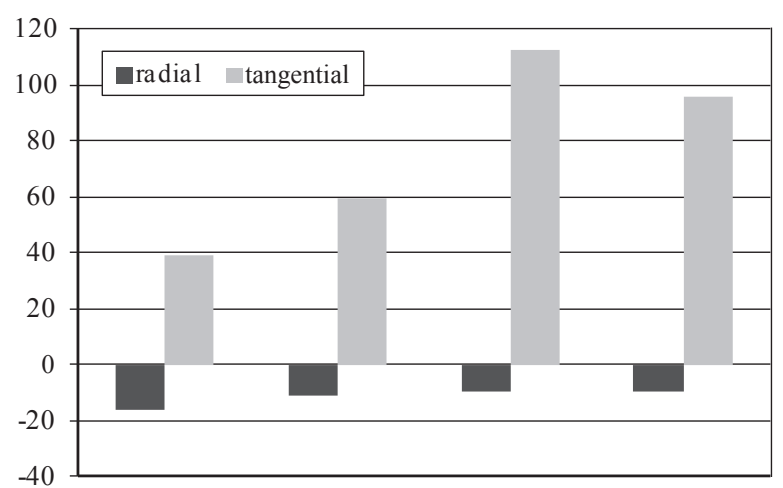

Figure 5 Change of TR on radial and tangential surfaces according to UT

Slika 5. Promjena smanjenja debljine radijalnih i tangenciajlnih uzoraka u odnosu prema kontrolnom uzorku
According to the results of WL and TR obtained from the heat treated Wild Cherry Wood, the following can be concluded:

1. In terms of both $\mathrm{WL}$ and TR, more abrasion occurred in the HT tangential test samples than in the UT samples. It is noteworthy that the results of HT were lower than those of UT in terms of both WL and TR in all loop groups of the radial test samples.

2. The abrasion of the I. loop was higher than the abrasion of the II. loop in all variations. This probably stems from the decrease of the abrasive feature of the sandpaper (S-42) depending on the increase of the loop. Some decrease in this feature of abrasive grains would inevitably occur as the number of loops increased. Thus, the abrasive etches, but it also puts pressure on the surface and compresses the surface as a result of the effect of the applied force.

\subsection{Withdrawal capacity of screws}

3.2. Čvrstoća držanja vijaka

Arithmetic mean values of the WCS results, the change of WCS according to UT, SD and Duncan test 
Table 2 Values and change of WCS, density values and variations

Tablica 2. Vrijednosti promjene WCS-a, vrijednosti gustoće i varijacije

\begin{tabular}{|c|c|c|c|c|c|c|c|}
\hline \multirow{2}{*}{$\begin{array}{l}\text { Test } \\
\text { samples } \\
\text { Uzorci } \downarrow\end{array}$} & & \multicolumn{3}{|c|}{$\begin{array}{c}\text { Radial surface } \\
\text { Radijalna površina }\end{array}$} & \multicolumn{3}{|c|}{$\begin{array}{c}\text { Tangential surface } \\
\text { Tangencijalna površina }\end{array}$} \\
\hline & & $\begin{array}{c}\text { WCS } \\
\mathrm{N} / \mathrm{mm}^{2} \\
\end{array}$ & $\begin{array}{c}\text { Reduction } \\
\text { Smanjenje \% }\end{array}$ & $\begin{array}{c}\text { Density } \\
\mathrm{kg} / \mathrm{m}^{3}\end{array}$ & $\begin{array}{c}\text { WCS } \\
\mathrm{N} / \mathrm{mm}^{2} \\
\end{array}$ & $\begin{array}{c}\text { Reduction } \\
\text { Smanjenje \% }\end{array}$ & $\begin{array}{c}\text { Density } \\
\mathrm{kg} / \mathrm{m}^{3}\end{array}$ \\
\hline \multirow[t]{2}{*}{ UT } & $\mathrm{M}$ & $16.76 \mathrm{C}^{*}$ & - & $585 \mathrm{D}$ & $15.5 \mathrm{C}$ & - & $579 \mathrm{C}$ \\
\hline & SD & 1.72 & - & - & 0.63 & - & - \\
\hline \multirow[t]{2}{*}{$\mathrm{HT}_{1}$} & $\mathrm{M}$ & $13.18 \mathrm{~B}$ & 21.3 & $559 \mathrm{C}$ & $15.16 \mathrm{C}$ & 2.1 & $565 \mathrm{BC}$ \\
\hline & SD & 1.43 & - & - & 1.33 & - & - \\
\hline \multirow[t]{2}{*}{$\mathrm{HT}_{2}$} & $\mathrm{M}$ & $12.58 \mathrm{~B}$ & 24.9 & $558 \mathrm{C}$ & $12.71 \mathrm{BC}$ & 18.0 & $546 \mathrm{BC}$ \\
\hline & SD & 0.57 & - & - & 2.96 & - & - \\
\hline \multirow[t]{2}{*}{$\mathrm{HT}_{3}$} & $\mathrm{M}$ & $8.40 \mathrm{~A}$ & 49.8 & $510 \mathrm{~B}$ & $10.59 \mathrm{AB}$ & 31.6 & $533 \mathrm{AB}$ \\
\hline & SD & 1.02 & - & - & 1.52 & - & - \\
\hline \multirow[t]{2}{*}{$\mathrm{HT}_{4}$} & $\mathrm{M}$ & $8.15 \mathrm{~A}$ & 51.37 & $469 \mathrm{~A}$ & $9.26 \mathrm{~A}$ & 40.2 & $491 \mathrm{~A}$ \\
\hline & SD & 1.53 & - & - & 0.7 & - & - \\
\hline
\end{tabular}

(*) The letters express the homogeneity groups according to Duncan test results. / Slova označuju homogene grupe prema Duncanovu testu.

results are given with the density of the test samples in Table 2.

As shown in Table 2, WCS decreases more than the UT in both radial direction and tangential direction, heat treated. Compared to UT, the highest decrease of WCS occurred in HT4, and the lowest occurred in the HT1 test samples.

Heat treatment resultes in a decrease in the density, and this reduction in density became even more pronounced as the duration and the temperature of the heat treatment increased. So, a relationship was observed between the decrease in density and the decrease in WCS. Kariz et al. (2013) and Percin and Ayan (2012) outlined that heat treatment affects the screws withdrawal capacity of wooden material because of various factors, one of which was the decrease in density that resulted from heat treatment.

Fig. 6 shows the effects of heat treatment on the withdrawal capacity of screws and the changes in wood density.

Fig. 6 shows that the withdrawal capacity of screws was compatible with decrease in the density during the heat treatment, and the extension of the duration of the treatment affected both radial and tangential surfaces.

\section{CONCLUSIONS}

4. ZAKLJUČAK

1. In heat treated Wild Cherry Wood, weight and thickness losses that occurred in 500 loops on the radial surfaces were less than the losses on the tangential surfaces. Although it is not very important for wall and ceiling coverings, it will be suitable to use the material primarily with a radial surface if it is heat-treated wooden material for floor coverings.

2. The differences of weight loss and thickness reduction between the 0-250 loop and the 250-500 loop indicated that careful consideration should be given to the applicability of the Taber method. In this regard, the loop numbers should be determined carefully to obtain objective results. Also, the S-42 sandpaper should be replaced after completing each sample process.

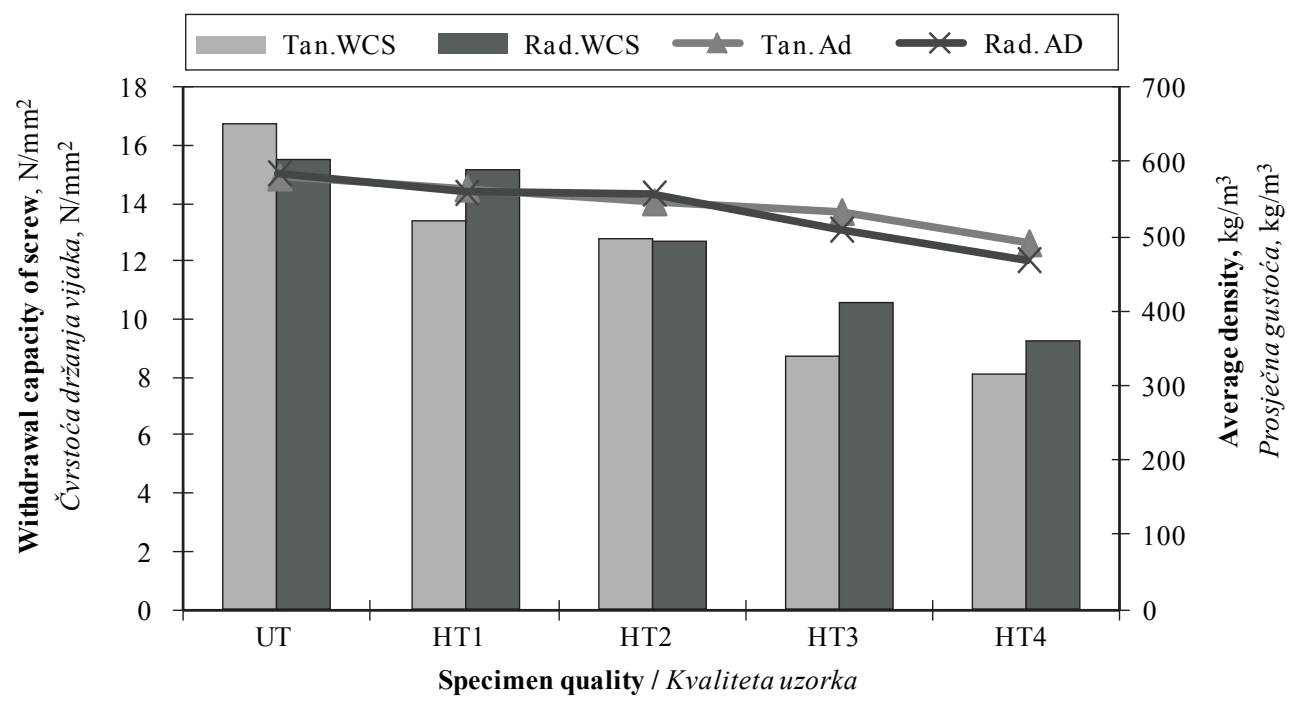

Figure 6 The effects of heat treatment on the withdrawal capacity of screws and changes in density Slika 6. Utjecaj toplinske obrade drva na čvrstoću držanja vijaka i promjenu gustoće 
3. In practice, both temperature and duration have negative effects on the withdrawal capacity of screws of heat treated Wild Cherry Wood, but the effect of temperature has a greater effect than the duration. The withdrawal capacity of screws was reduced by $50 \%$ in the trials with flat head screws in heat treated Wild Cherry Wood.

\section{REFERENCES}

5. LITERATURA

1. Anonymous, 2003: ThermoWood Handbook, Finish ThermoWood Association, Helsinki- Finland.

2. Anonymous, 2014: http://www.imalpal.com/en/scheda. php?pr=114.

3. Brischke, C.; Welzbacher, C. R.; Rapp, A. O., 2004: A new method for testing the abrasion resistance of thermally modified wood, Workshop COST Action E37 'Managing the Environmental Risk' Reinbek - Germany, 8th - 9th November Federal Research Centre of Forestry and Forest Products (BFH), Leuschnerstr. 91, D-21031 Hamburg.

4. Berkel, A., 1970: Wood Technology (First volume), Istanbul University, Kurtulmuş Printing House.

5. DIN EN 438-2, 2005. High-pressure decorative laminates (HPL) - Sheets based on thermosetting resins (usually called laminates) - Part 2: Determination of properties, German.

6. Eşen, D.; Yıldız, O.; Kulaç, Ş.; Sarginci, M., 2005: Neglected valuable leafy of Turkey forest's: Wild Cherry (Cerasus avium (L.) Monench). J Chamber of Forest Engineer (TBMMO), 2: 18-22.

7. Gunduz, G.; Korkut, S.; Korkut, D. S., 2008: The effects of heat treatment on physical and technological properties and surface roughness of Camiyanı Black Pine (Pinus nigra Arn. subsp. pallasiana var. pallasiana) wood. Bioresource Technology, 99 (7): 2275-2280 http://dx.doi.org/10.1016/j.biortech.2007.05.015

8. Kocaefe, D.; Poncsak S.; Boluk, Y., 2008: Effect of thermal treatment on the chemical composition and mechanical properties of birch and apsen. Bioresources, 3 (2): 517-537.

9. Kariz, M.; Kuzman, M. K.; Sernek, M., 2013: The Effect of Heat Treatment on the Withdrawal Capacity of Screws in Spruce Wood. Bioresources, 8(3): 4340-4348 http://dx.doi.org/10.15376/biores.8.3.4340-4348.

10. Perçin, O.; Ayan, S., 2012: Determination of screw withdrawal strength in heat treated wood material, Journal of Advanced Sciences, 1 (1): 57-68.

11. Swacyna, I.; Kedzierski, A.; Tomusiak, A.; Cichy, A.; Rozanska, A., 2011: Hardness and wear resistance tests of the wood species most frequently used in flooring panels, Annals of Warsaw University of Life Sciences SGGW Forestry and Wood Technology, 76: 82-87.

12. ***TS EN 15185, 2013: Furniture - Assessment of the surface resistance to abrasion, Turkish Standart Institution.

13. ***TS EN 320, 1999: Determine of withdrawal capacity of screw for Fiberboards, TSE, Ankara.

14. ***TS 432-1 EN ISO 1478, 2000: Tapping screws thread, Turkish Standard Institution.

15. ***TS 4176, 1984: Wood - Sampling Sample Trees and Long for Determination of Physical and Mechanical Properties of Wood in Homogeneous Stands, Turkish Standard Institution.

16. ***TS 2470, 1976: Wood-Sampling Methods And General Requirements For Physical And Mechanical Tests, Turkish Standard Institution.

17. ***TS EN 15679, 2010: Thermal Modified Timber - Definitions and characteristics. Turkish Standard Institution.

18. Welzbacher, C. R.; Brischke, C.; Rapp, A. O.; Koch, S.; Sabine Hofer, S., 2009. Performance of thermally modified timber (TMT) in outdoor application - durability, abrasion and optical appearance. Drvna industrija, 60 (2): 75-82.

\section{Corresponding address:}

Assoc. Prof. SULEYMAN KORKUT, Ph.D.

Duzce University, Faculty of Forestry

Department of Forest Industry Engineering

81620 Beciyorukler

Campus Duzce - TURKEY

e-mail: suleymankorkut@duzce.edu.tr 